\title{
Trophic ecology of Patagonian flounder Paralichthys patagonicus (Jordan, 1889) in the Argentine-Uruguayan Coastal Ecosystem
}

\author{
Gonzalo H. Troccoli ${ }^{1}$, Andrés C. Milessi ${ }^{2,3,}{ }^{*}$, Noemí Mari ${ }^{1}$, Daniel Figueroa ${ }^{4}$ and Agustín M. De Wysiecki ${ }^{5}$ \\ ${ }^{1}$ Instituto Nacional de Investigación y Desarrollo Pesquero (INIDEP), Paseo Victoria Ocampo No 1, Escollera Norte, B7602HSA - \\ Mar del Plata, Argentina. ${ }^{2}$ Comisión de Investigaciones Científicas de la Provincia de Buenos Aires (CIC), Argentina. ${ }^{3}$ Organización para la \\ Conservación de Cetáceos (OCC), Uruguay. ${ }^{4}$ Laboratorio de Biología de Peces, Instituto de Investigaciones Marinas y Costeras \\ (IIMyC-CONICET), Facultad de Ciencias Exactas y Naturales, Universidad Nacional de Mar del Plata (UNMdP), Consejo Nacional de \\ Investigaciones Científicas y Técnicas (CONICET), Argentina. ${ }^{5}$ Centro para el Estudio de Sistemas Marinos (CESIMAR), \\ Consejo Nacional de Investigaciones Científicas y Técnicas (CONICET), Boulevard Brown 2915, U9120ACD - Puerto Madryn, Argentina. \\ ORCID Gonzalo H. Troccoli (D) https://orcid.org/0000-0002-0057-4325, Andrés C. Milessi (D) https://orcid.org/0000-0003-3897-4970, \\ Noemi Mari (D) https://orcid.org/0000-0003-2278-6510, Daniel Figueroa (D) https://orcid.org/0000-0003-3258-1092, \\ Agustín M. De Wysiecki (D) https://orcid.org/0000-0002-0506-3495
}

Marine and Fishery Sciences MAFIS

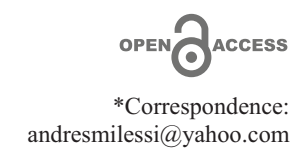

Received: 5 September 2021 Accepted: 1 December 2021

ISSN 2683-7595 (print) ISSN 2683-7951 (online)

https://ojs.inidep.edu.ar

Journal of the Instituto Nacional de Investigación y Desarrollo Pesquero (INIDEP)

This work is licensed under a Creative Commons AttributionNonCommercial-ShareAlike 4.0 International License

\begin{abstract}
Food habits and diet composition of Patagonian flounder Paralichthys patagonicus (Jordan, 1889) were studied on the basis of stomach content analyses from 828 specimens (512 females, 304 males, 12 unsexed) collected during 16 commercial cruises between February 2009 and April 2010 in the Argentine-Uruguayan Coastal Ecosystem ( $\left.34^{\circ} \mathrm{S}-41^{\circ} \mathrm{S}\right)$. A total of 272 stomachs (32.9\%) contained food (184 females and 84 males), among which 20 prey taxa were identified. The most important prey category was pelagic fish, primarily Argentine anchovy (Engraulis anchoita), followed by rough scad (Trachurus lathami). Evidence showed that females consumed a higher total wet weight of prey compared to males. Results also suggested a specialised diet over E. anchoita, across all sex and size groups. The estimated trophic level for the population of $P$. patagonicus was 4.16. This study suggests that $P$. patagonicus is a tertiary piscivorous consumer of the trophic food web in the region, and reveals changes in the prey consumption compared with previous studies.
\end{abstract}

Key words: Diet, feeding strategy, spatio-temporal variation, trophic level.

Ecología trófica del lenguado patagónico Paralichthys patagonicus (Jordan, 1889) en el Ecosistema Costero Argentino-Uruguayo

RESUMEN. Se estudiaron los hábitos alimentarios y la composición de la dieta del lenguado patagónico Paralichthys patagonicus (Jordan, 1889) sobre la base del análisis del contenido estomacal de 828 especímenes (512 hembras, 304 machos, 12 indeterminados) recolectados durante 16 cruceros comerciales entre febrero de 2009 y abril de 2010 en el Ecosistema Costero ArgentinoUruguayo $\left(34^{\circ} \mathrm{S}-41^{\circ} \mathrm{S}\right)$. Un total de 272 estómagos (32,9\%) contenían alimento (184 hembras y 84 machos), entre los que se identificaron 20 taxones de presas. La categoría de presa más importante fue los peces pelágicos, principalmente la anchoíta argentina (Engraulis anchoita), seguida por el surel (Trachurus lathami). La evidencia mostró que las hembras consumieron un mayor peso húmedo total de presa en comparación con los machos. Los resultados también sugirieron una dieta especializada sobre E. anchoita para todos los sexos y tamaños. El nivel trófico estimado para toda la población de $P$. patagonicus fue 4,16. Este estudio sugiere que $P$. patagonicus es un consumidor piscívoro terciario de la trama trófica en la región, y revela cambios importantes en el consumo de presas en comparación con estudios previos.

Palabras clave: Dieta, estrategia alimenticia, variación espacio-temporal, nivel trófico. 


\section{INTRODUCTION}

Predation in nature is a central ecological process as it contributes to understanding the interactions of predators with their prey within an ecosystem (Elton 1927). Today, it is known that relationships between two or more species are described as nodes of a food web which can interact with each other and, therefore, any alteration can affect its stability (Lawton and Pimm 1978; Sterner et al. 1997).

The main coastal fishery in Argentina is carried out along the Argentine-Uruguayan Coastal Ecosystem (AUCE, $34^{\circ} \mathrm{S}-41^{\circ} \mathrm{S}$ ), namely the Bonaerense Coastal Fishery (Carozza et al. 2004). More than 40 species are caught including crustaceans, molluscs and fish. The latter are grouped into the 'varied coastal', which is composed of about 30 species, both bony and cartilaginous fish (Lasta et al. 1998; Massa et al. 2004). In 2009, declared landings of 30 species making up the coastal assemblage was $105,361 \mathrm{t}$, from which $86.7 \%$ was obtained within the AUCE (Fernández Aráoz et al. 2010).

In particular, the Patagonian flounder (Paralichthys patagonicus) is one of the main fishing resources in the AUCE, due to both its excellent meat quality and its high market price (Fabré 1992). As a result of its high commercial importance, overfishing is a major threat in the region, leading this species to a vulnerable conservation status (Riestra et al. 2020). Over the past decades, annual catches ranged from 6,000 to $7,000 \mathrm{t}$ year $^{-1}$, but more recently they shifted to an average of $\sim 3,200 \mathrm{t}^{\text {year-1 }}{ }^{-1}$ (MAGyP 2021). In 2008, for example, catches of $P$. patagonicus contributed to $7 \%(6,930 \mathrm{t})$ of total declared landings in the AUCE (Rico and Lagos 2010), whereas in 2009 , this percentage slightly decreased to $6,4 \%$ $(5,890$ t) (Fernández Aráoz et al. 2010). During 2020, the capture of flounders in Argentina and Uruguay diminished significantly to $1,891 \mathrm{t}$, accounting for $2.2 \%$ of total harvest (CTMFM 2021). Nevertheless, P. patagonicus continues to be the one that predominates the catches among the four species of flounder landed in the AUCE (Rico and Perrotta 2009; Rico 2010).

Paralichthys patagonicus is a benthic species inhabiting soft bottoms (Menni 1983), characterized as an ichthyophagous as well as a generalist mesopredator (Carneiro 1995; Sánchez and Díaz de Astarloa 1999). Its diet is based on fish with demersal-benthic habits (40.4\%), mainly banded cusk-eel Raneya brasiliensis, and followed by pelagic fish (31.0\%), including rough scad Trachurus lathami and Argentine anchovy Engraulis anchoita (Sánchez and Díaz de Astarloa 1999). Previous studies were based on qualitative analysis and did not provide the feeding strategy of $P$. patagonicus, nor its trophic role or any changes in diet concerning sex and size. Therefore, this work aimed to quantitatively determine the diet composition of $P$. patagonicus and find possible differences in prey consumption between sex and size groups, as well as its feeding strategies and trophic position in the AUCE.

MATERIALS AND METHODS

\section{Study area}

The study area is located in the AUCE region at the northern part of the Argentine Continental Shelf, between $34^{\circ} \mathrm{S}$ and $41^{\circ} \mathrm{S}$ and from the coastline to the $50 \mathrm{~m}$ deep isobath (Figure 1). On a large scale, the AUCE is influenced by various sources of oceanographic variability. In the northern area, it receives the influence of the coastal branch of the Brazil Current and the freshwater discharge from the Río de la Plata (Guerrero et al. 1997). In the southern area, it is influenced by the discharge of the Negro and Colorado rivers and the salty waters of San Matías Gulf (Lucas et al. 2005). In the outer eastern waters, it receives the 


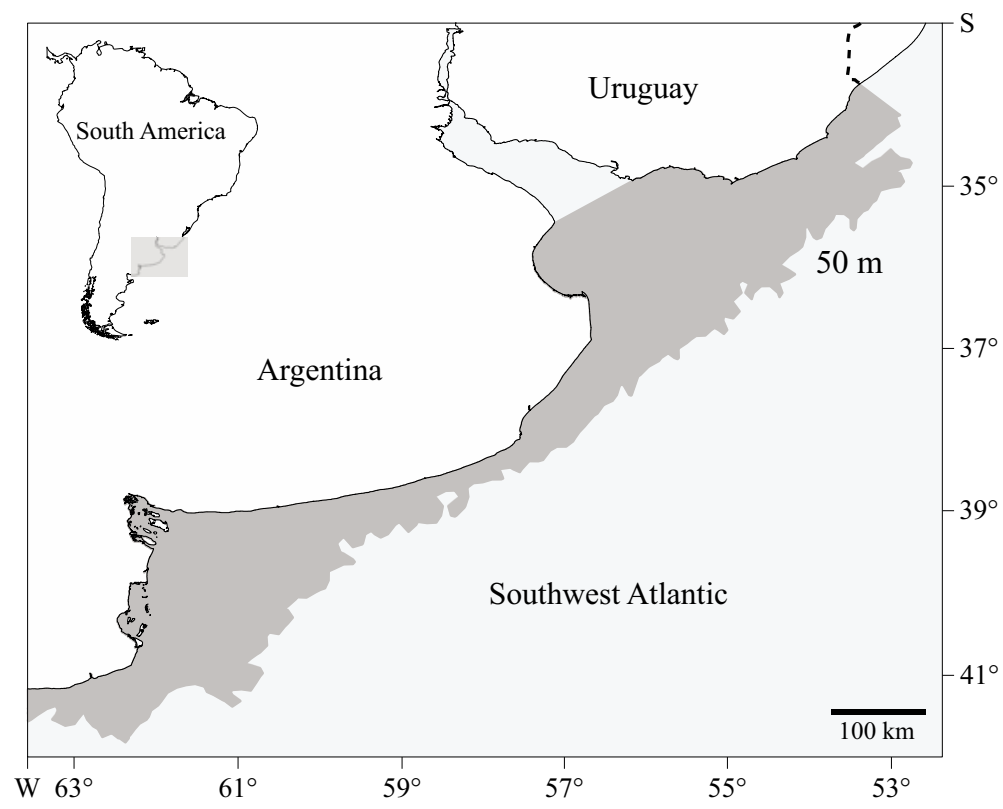

Figure 1. Study area (grey shade) from which samples were taken within the Argentine-Uruguayan Coastal Ecosystem (AUCE), delimited by the $50 \mathrm{~m}$ isobath.

influence of the Continental Shelf Current (Lucas et al. 2005).

\section{Data sources}

P. patagonicus were obtained from 16 fishery landings of the commercial coastal fleet, carried out between February 2009 and April 2010 in the AUCE. Total length $\left(L_{\mathrm{T}}\right.$, to the nearest $\left.\mathrm{cm}\right)$, total wet weight ( $W_{\mathrm{T}}$, to the nearest $\left.\mathrm{g}\right)$ and sex were recorded from each specimen, and stomachs were frozen to analyse prey composition.

\section{Stomach content analysis}

Prey items were identified to the lowest possible taxonomic level, counted and weighed. In the case of fish remains such as otoliths, $L_{\mathrm{T}}-W_{\mathrm{T}}$ and otolith size- $L_{\mathrm{T}}$ regression curves to estimate the $L_{\mathrm{T}}$ and $W_{\mathrm{T}}$ of the prey were used (Koen Alonso et al. 1998; Waessle et al. 2003; Díaz de Astarloa 2005; Barquete et al. 2008). In order to quantify the importance of each prey item in the diet of $P$. patagonicus, the percentage in number $(\% \mathrm{~N})$, percentage in $W_{\mathrm{T}}(\% \mathrm{~W})$, frequency of occurrence $(\% \mathrm{FO})$, Index of Relative Importance or IRI [IRI $i$ $=\% \mathrm{FO} i \times(\% \mathrm{~N} i+\% \mathrm{~W} i)$ for each prey item $i]$ (Pinkas et al. 1971), and the IRI expressed as a percentage (\%IRI, Cortés 1997) were calculated.

Representativeness of stomach samples in the description of the diet of species was analysed by the minimum sample size and the intrinsic variability using randomization that considered 300,000 arrangements that produced curves for accumulated prey groups (i.e. pelagic fish, demersal fish, benthic fish, molluscs and crustaceans). For each randomization, the minimum, mean, maximum and coefficient of variation were obtained, which made possible to assess whether analysed sample met the minimum sample size.

\section{Variations in the diet with sex and size}

Possible quantitative differences in diet between females and males, and among size groups of $P$. patagonicus, were analysed by running a 
non-parametric Mann-Whitney and Kruskal-Wallis tests, respectively. Data were arranged into three different size groups according to the criteria provided by previous growth studies of the species (Riestra 2010): Group I (22-34 $\mathrm{cm} L_{\mathrm{T}} ; 2$ to 4 years), Group II (35-47 $\mathrm{cm} L_{\mathrm{T}} ; 4$ to 7 years) and Group III ( $>47 \mathrm{~cm} L_{T} ;>8$ years). In addition, prey type composition (main prey categories) was examined between sexes and among size groups.

\section{Feeding strategy}

In order to determine the feeding strategy (i.e. generalist or specialist) of $P$. patagonicus and the importance of the prey, the graphic method of Amundsen et al. (1996) was used. The specific abundance of prey $i$ was plotted against $\% \mathrm{FO} i$.

\section{Trophic level}

The trophic level (TL) makes reference to the position of a species or population in the trophic web and its classification ranges from primary producers with a value of 1 to large top predators with values of 4 or 5 (Lindeman 1942). In the present work, the fractional form was used as suggested by Odum and Heald (1975), and then, TL was calculated for the population of $P$. patagonicus by applying the methodology suggested by Cortés (1999):

$\mathrm{TL}=1+\left(\sum_{j=1}^{n} \mathrm{P}_{j} \times \mathrm{TL}_{j}\right)$

where TL is the trophic level of $P$. patagonicus (predator), $\mathrm{P}_{j}$ is the proportion of the prey item $j$ in the predator's stomach, $\mathrm{TL}_{j}$ is the trophic level of each prey item $j$, and $n$ is the number of prey items recorded in the stomach of the predator. Trophic level of prey was obtained from online resources (Froese and Pauly 2019) and published literature (Jaureguizar and Milessi 2008; Milessi 2008).

\section{RESULTS}

\section{Stomach contents}

Out of 828 stomachs of $P$. patagonicus analysed, $272(32.9 \%)$ presented prey contents, of which 184 were females and 84 males. Of the stomachs with contents, $36(13.24 \%)$ corresponded to size group I, $176(64.71 \%)$ to size group II, and $60(22.05 \%)$ to size group III. In a very low percentage of specimens $(1.45 \%)$, the sex could not be determined. The cumulative curves of the number of prey categories as a function of the number of stomachs sampled with prey content indicated that the number of samples was sufficient to describe and quantitatively analyse the diet of $P$. patagonicus and compare it between size groups and sexes (Figure 2).

Twenty prey items were identified, corresponding to three taxonomic groups: fish, molluscs and crustaceans. Fish were the most frequently encountered prey $(\% \mathrm{FO}=87.55)$, followed by crustaceans $(\% \mathrm{FO}=8.20)$ and cephalopod $(\% \mathrm{FO}$ = 3.41) $($ Table 1). The most frequent prey item was $E$. anchoita $(\% \mathrm{FO}=37.60)$, followed by $T$. lathami $(\% \mathrm{FO}=18.12)$ and $R$. brasiliensis $(\% \mathrm{FO}$ $=9.19)$. The most common prey item was $E$. anchoita $(\% \mathrm{~N}=52.94)$, followed by $T$. lathami $(\% \mathrm{~N}=18.21)$ (Table 1$)$. Regarding the percentage by weight, fish were the most important group $(\% \mathrm{~W}=96.53)$, followed by molluscs $(\% \mathrm{~W}$ $=2.31)$ and crustaceans $(\% \mathrm{~W}=0.71)$ (Table 1$)$. The best-represented species by weight were $E$. anchoita $(\% \mathrm{~W}=36.62)$ and $T$. lathami $(\% \mathrm{~W}=$ 26.17). The Relative Importance Index (\%IRI) indicated that the most important item in the diet was fish (98.73), followed by crustaceans (0.91) and cephalopods (0.35) (Table 1). Among fish prey, the species with the highest contribution was $E$. anchoita $(\% \mathrm{IRI}=74.25)$, followed by $T$. lathami $(\% \mathrm{IRI}=18.22)$ and $R$. brasiliensis $(\% \mathrm{IRI}$ =4.18). Among cephalopod prey, squid (Loligo 

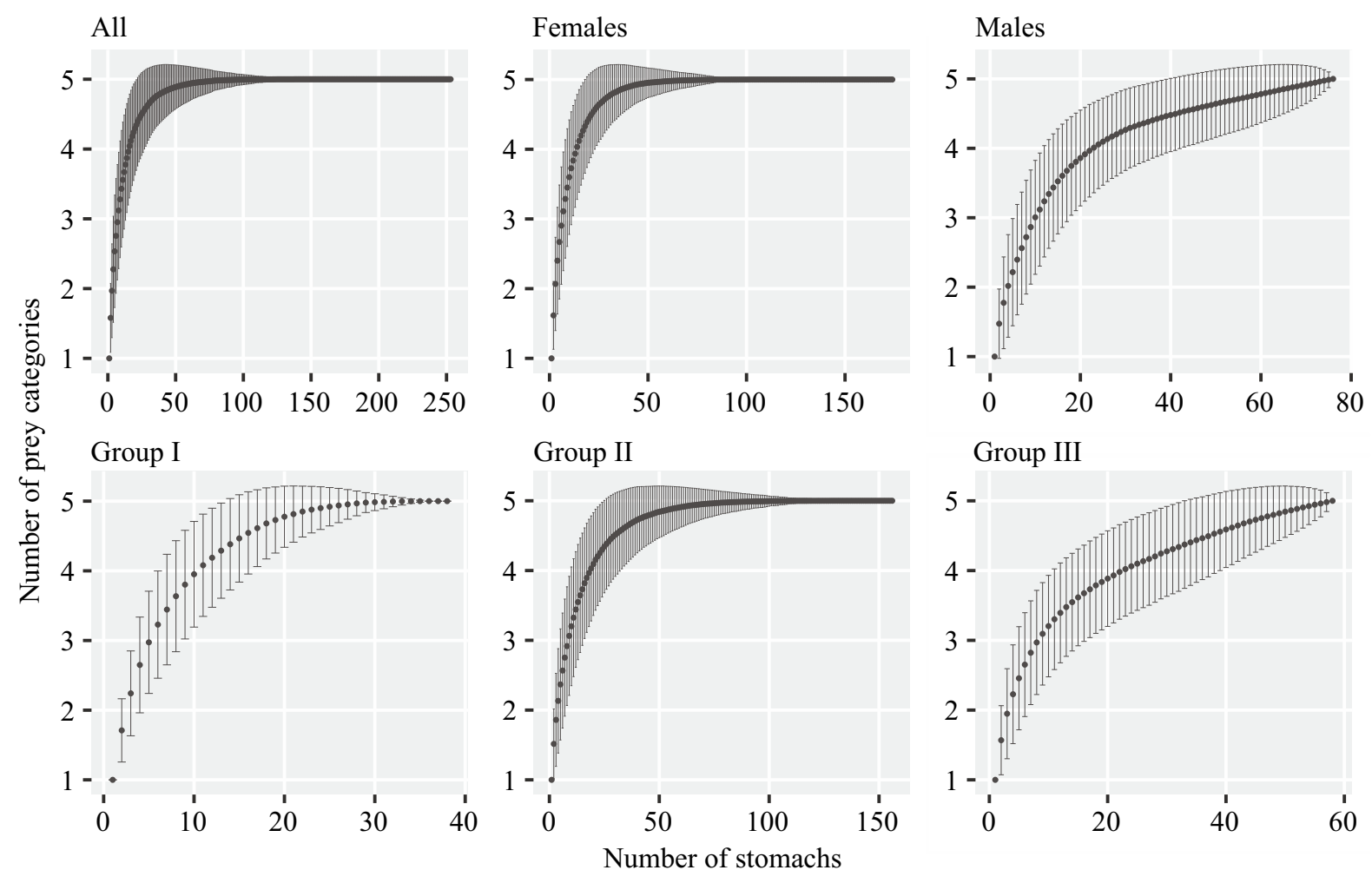

Group III

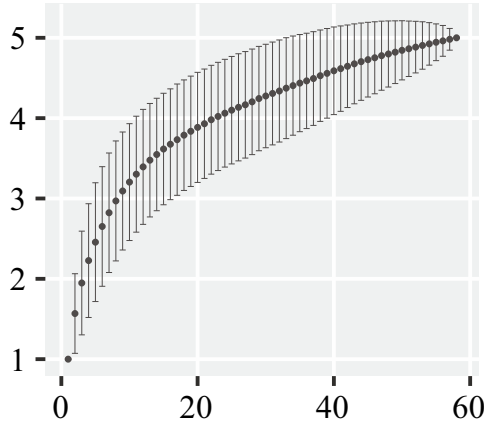

Figure 2. Cumulative number of prey categories of Patagonian flounder Paralichthys patagonicus as a function of stomachs sampled with prey content, arranged by sex or size group. Group I $=23-34 \mathrm{~cm} L_{\mathrm{T}}$, Group II $=35-47 \mathrm{~cm} L_{\mathrm{T}}$, and Group $\mathrm{III}=>47 \mathrm{~cm} L_{\mathrm{T}}$. Mean values are denoted by points and standard deviation by error bars. Stomachs with only bony fish and/or unidentified rests were excluded from this analysis.

sanpaulensis) accounted for $0.35 \%$, and the Argentine red shrimp (Pleoticus muelleri) represented $0.86 \%$ among crustaceans.

\section{Variations in the diet according to sex and size}

Results revealed that females consumed a greater amount of food than males, both in number and weight (Figure $3 \mathrm{~A})$. Statistically significant differences between sexes were observed in both the number (Mann-Whitney, $\mathrm{W}=8579 ; p=$ 0.006), and weight (Mann-Whitney, $\mathrm{W}=9910 ; p$ $<0.001$ ) of prey consumed. Size groups consumed the same amount of prey in number but not in weight, being size group III the category consuming the greatest weight of prey (Figure 3 B). Statistical analysis indicated no significant differences in number of prey consumed by size groups (Kruskal-Wallis, $\mathrm{H}=4.74, p=0.192$ ) and significant differences in weight of prey (Kruskal-Wallis, $\mathrm{H}=39.14, p<0.001$ ).

Pelagic fish were by far the predominant prey category both in number and weight in stomachs of all sex and size groups (Figure $4 \mathrm{~A}$ and B). The second most important prey category for group I was crustaceans, while benthic and demersal fish (number and weight) for groups II and III (Figure 4 B). Consumption of crustaceans was negligible across specimens larger than $47 \mathrm{~cm} L_{\mathrm{T}}$.

\section{Feeding strategy}

Based on Amundsen's graphical method, $P$. patagonicus presented a specialist type strategy 
Table 1. Diet composition of Patagonian flounder (Paralichthys patagonicus) caught within the Argentine-Uruguayan Coastal Ecosystem (AUCE). Frequency of occurrence $(\% \mathrm{FO})$, number $(\% \mathrm{~N})$, total wet weight $(\% \mathrm{~W})$, and Index of Relative Importance $(\% \mathrm{IRI})$ were indicated and expressed in percentages. TL $=$ trophic level.

\begin{tabular}{lcrrrr}
\hline Prey & TL & $\% \mathrm{~N}$ & $\% \mathrm{FO}$ & $\% \mathrm{~W}$ & $\% \mathrm{IRI}$ \\
\hline Chordata & & & & & \\
Osteichthyes & & $\mathbf{8 8 . 5 1}$ & $\mathbf{8 7 . 1 8}$ & $\mathbf{9 6 . 5 3}$ & $\mathbf{9 8 . 7 3}$ \\
$\quad$ Conger orbignyanus & 3.40 & 1.68 & 2.21 & 1.68 & 0.16 \\
$\quad$ Cynoscion guatucupa & 3.74 & 3.36 & 4.41 & 6.41 & 0.97 \\
Dules auriga & 3.49 & 1.40 & 1.47 & 2.91 & 0.14 \\
Engraulis anchoita & 2.73 & 52.94 & 37.60 & 36.62 & 74.25 \\
Menticirrhus americanus & 3.73 & 0.28 & 0.37 & 0.04 & 0.00 \\
Mullus argentinae & 3.73 & 0.84 & 1.10 & 0.36 & 0.03 \\
Prionotus nudigula & 3.73 & 0.28 & 0.37 & 0.27 & 0.00 \\
Raneya brasiliensis & 3.73 & 7.28 & 9.19 & 13.89 & 4.18 \\
Symphurus spp. & 3.73 & 0.28 & 0.37 & 2.30 & 0.02 \\
Trachurus lathami & 3.51 & 18.21 & 18.12 & 26.17 & 18.22 \\
Umbrina canosai & 3.73 & 1.12 & 1.47 & 2.57 & 0.12 \\
Urophycis brasiliensis & 3.80 & 0.84 & 1.10 & 0.68 & 0.04 \\
$\quad$ Remains & - & - & 9.40 & 2.63 & 0.60 \\
Chondrichthyes & - & $\mathbf{0 . 2 8}$ & $\mathbf{0 . 3 7}$ & $\mathbf{0 . 3 2}$ & $\mathbf{0 . 0 0}$ \\
Rajidae & 3.59 & 0.28 & 0.37 & 0.32 & 0.00
\end{tabular}

Mollusca

Cephalopoda

Loligo sanpaulensis

3.08

3.41

2.31

$\mathbf{0 . 3 5}$

Octopus spp.

$3.04 \quad 2.80$

3.35

2.09

0.35

3.20

0.28

0.37

0.22

0.00

Arthropoda

Crustacea

Grapsidae

8.13

8.20

0.71

0.91

Heterosquilla platensis

2.00

1.68

1.10

0.03

0.04

Leurocyclus tuberculosus

2.00

0.56

0.74

0.01

Pinixa patagonica

0.28

0.37

0.26

0.00

Pleoticus muelleri

2.00

0.28

0.37

0.00

0.00

2.20

5.33

5.62

0.00

0.86

Unidentified remains

0.84

0.13

0.01

due to the consumption of E. anchoita and T. lathami as main prey items (Figure 5). Argentine anchovy was the most selected prey among both female and male groups (Figure 5). Juvenile sizes of flounder specialized only on E. anchoita, whereas intermediate sizes on E. anchoita and $T$. lathami, and larger sizes on E. anchoita, T. latha$m i$ and $R$. brasiliensis (Figure 5). 

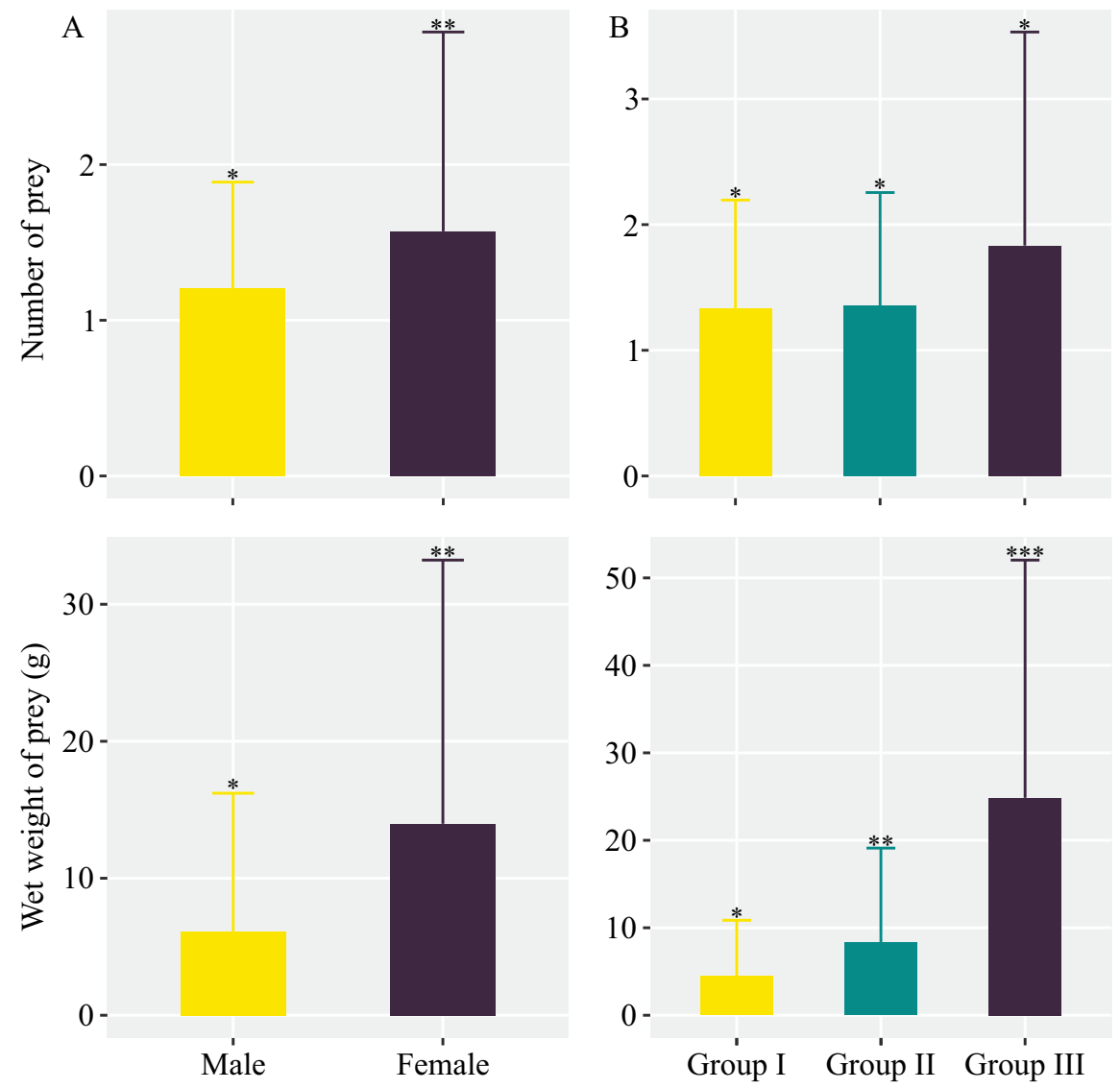

Figure 3. Diet composition (in number and wet weight of prey) of Patagonian flounder Paralichthys patagonicus arranged by sex (A) and size groups (B). Group I $=23-34 \mathrm{~cm} L_{\mathrm{T}}$, Group II $=35-47 \mathrm{~cm} L_{\mathrm{T}}$, and Group III $=>47 \mathrm{~cm} L_{\mathrm{T}}$. Asterisks indicate significant differences.

\section{Trophic level}

Estimated TL for the population of $P$. patagonicus between 2009 and 2010 was 4.16, with females presenting a value of 4.18 and males a value of 4.10 .

\section{DISCUSSION}

Patagonian flounder diet presented 20 prey items and was specialized in pelagic fish. The main consumed species were E. anchoita, followed by $T$. lathami and $R$. brasiliensis. This study supports previous observations that $P$. patagonicus is an ichthyophagous predator, which bases its diet preferentially on E. anchoi$t a$, allowing it to be allocated as a tertiary consumer in the AUCE food web. The number of stomachs analysed was statistically adequate to describe the diet of $P$. patagonicus. Only 33\% of the analysed specimens presented food in their stomachs, which is consistent with other studies on ichthyophagous bony fishes and flounder species (Carneiro 1995; Sánchez and Díaz de Astarloa 1999; Link et al. 2002). A high number of empty stomachs could be a consequence of fish suffering stress or water pressure differences during their extraction from the aquatic 

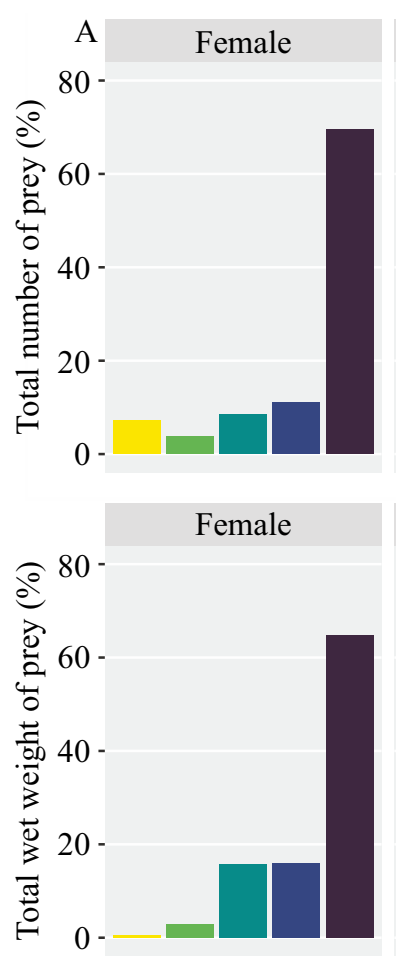

Crustaceans

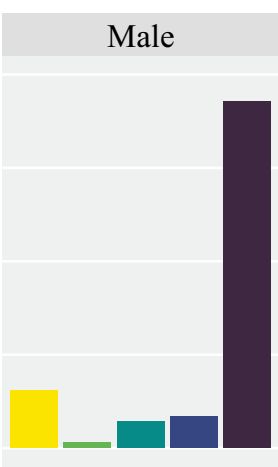

Male

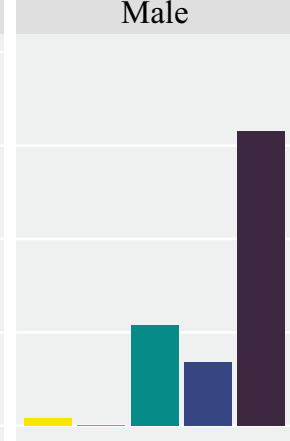

Molluscs

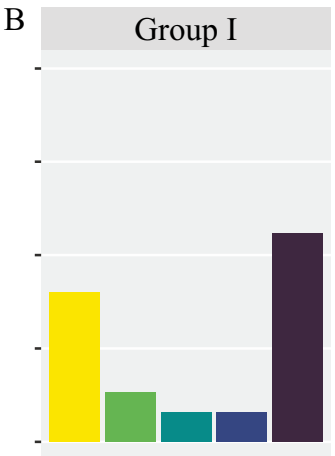

Group I

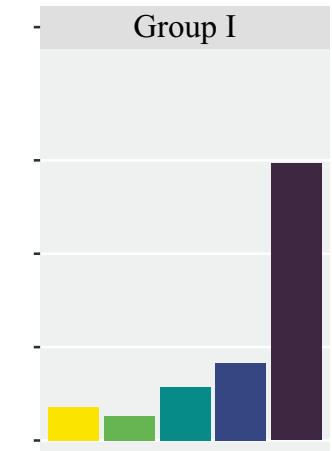

Group II

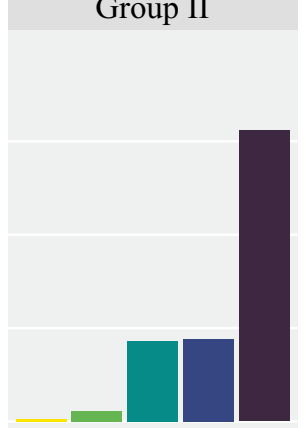

Group III
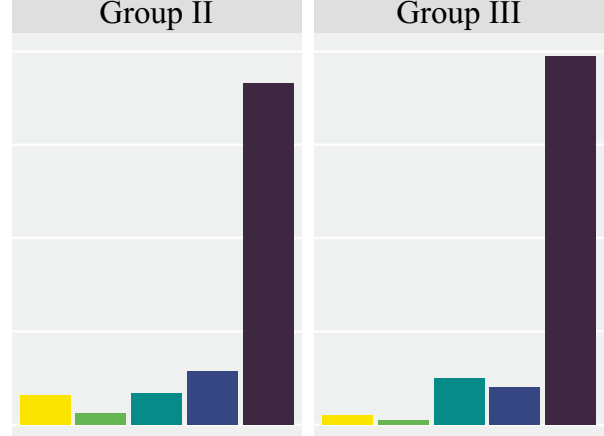

Group III

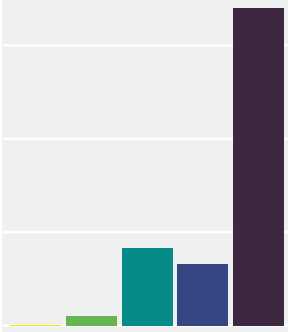

Figure 4. Prey type composition of Patagonian flounder Paralichthys patagonicus arraged by sex (A) and size groups (B). Values are expressed as percentage of total number and wet weight of main prey categories. Group I $=23-34 \mathrm{~cm} L_{\mathrm{T}}$, Group II $=35-47 \mathrm{~cm} L_{\mathrm{T}}$, and Group III $=>47 \mathrm{~cm} L_{\mathrm{T}}$.

environment, a process manifested with the stomach eversion or regurgitation of contents (Bowman 1986). In particular, regurgitations could be one factor explaining why the proportion of individuals with stomach content did not exceed $1 / 3$ of the total, as it was repeatedly observed in $P$. patagonicus being caught on fishing gear (pers. obs. A Milessi). In addition, the samples used in this study came from bottom trawl fishing operations which are less likely to have associated bias regarding regurgitation rate, compared to other fishing gears (e.g. longlines).

Patagonian flounder bases its diet primarily on bony fish. Ichthyophagy seems to be a characteristic of intermediate and large-sized flounders like the species studied here, e.g., P. dentatus
(Link et al. 2002), P. orbignyanus (Norbis and Galli 2004; López Cazorla and Forte 2005); Syacium micrurum (Marques et al. 2009), and Cyclopsetta panamensis (Amezcua and Portillo 2010), with a less important presence of crustaceans and molluscs in the diet. This characteristic is common in P. patagonicus from both southern Brazil (Carneiro 1995) and AUCE (Sánchez and Díaz de Astarloa 1999). However, $P$. patagonicus have changed past feeding patterns observed in the AUCE between years 19921993, when the diet was based predominantly on $R$. brasiliensis, followed by T. lathami and to a lesser extent by E. anchoita (Sánchez and Díaz de Astarloa 1999). This situation was also observed in other piscivorous fish like Percophis brasiliensis (Milessi and Marí 2012) and 


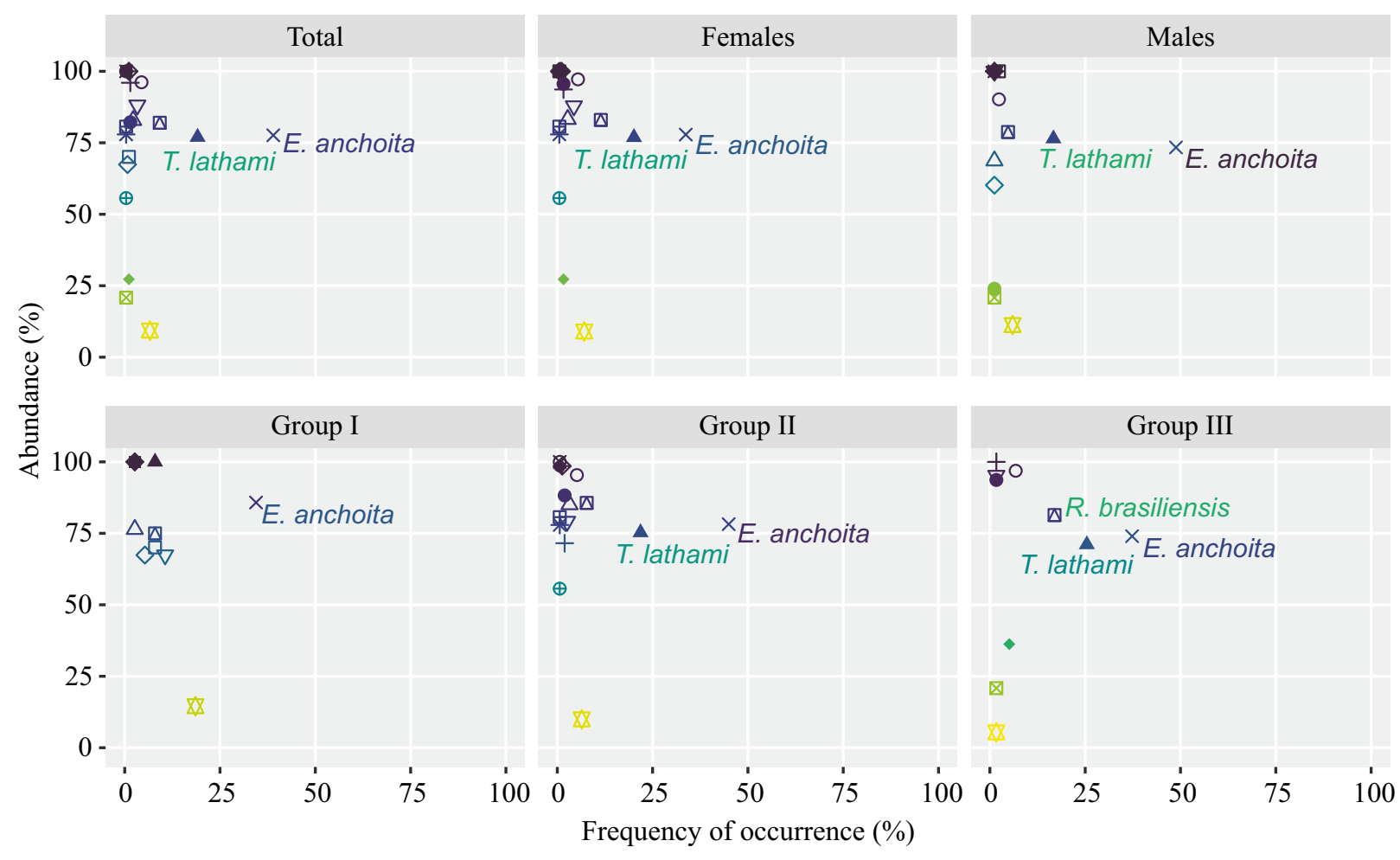

Figure 5. Abundance ( $\%$ total wet weight) versus frequency of occurrence ( $\%$ in number) of each prey found in stomachs of Patagonian flounder (Paralichthys patagonicus) arranged by sex and size. Group I = 23-34 $\mathrm{cm} L_{\mathrm{T}}$, Group II = 35-47 $\mathrm{cm}$ $L_{\mathrm{T}}$, and Group III $=>47 \mathrm{~cm} L_{\mathrm{T}}$. The analysis is based on the method in Amundsen et al. (1996) to determine feeding strategies of fish. Each prey is represented by a unique symbol; only names from abundant and frequently occurring prey are shown to facilitate visualization. Darker colours in symbols and prey names indicate higher abundance and frequency of occurrence, respectively.

Squalus acanthias (Belleggia et al. 2012), which would reflect a change in the structure of the AUCE trophic web, mainly due to fishing exploitation (Jaureguizar and Milessi 2008). Another explanation for the observed shift between past and present diet may be due to a variation in the spatial operability of the coastal fishing fleet, which currently operates in areas that were not previously used, and consequently, prey captured by $P$. patagonicus in the present could be different from those found in stomachs from previous studies.

Statistical differences in diet between sexes found in $P$. patagonicus are likely a result of females consuming more prey both in number and weight because they attain larger sizes than males (Riestra 2010), and therefore have a higher consumption rate, greater stomach capacity and higher energy requirements (e.g. Scharf et al. 2000; Vögler et al. 2009). Although not possible to evaluate in this study, it has been proposed that there is a spatial overlap between sexes (Riestra 2010), suggesting that females and males would feed on the same prey but in different quantities. This last suggestion is in line with a study carried out on the Uruguayan coast, where no differences were observed in the prey type consumption between sexes of $P$. patagonicus (Correa 2011).

Furthermore, Amundsen graphical results indicated that $P$. patagonicus is specialized in consuming E. anchoita and T. lathami, and this pref- 
erence increased with size. This was expected given that $E$. anchoita is the most abundant fish species in the AUCE with a biomass estimated between 1,000,000 and 5,000,000 $\mathrm{t}$ (Hansen and Madirolas 1996; Hansen et al. 2007; Pájaro et al. 2009), it represents the main food source not only for $P$. patagonicus but also for other teleosts (Bergonzi 1997; Sánchez 2002; Giberto 2008, Milessi and Marí 2012) and chondrichthyans (Vögler et al. 2003; Belleggia et al. 2011), as well as seabirds (Silva et al. 2000; Mauco et al. 2001; Mauco and Favero 2004; Barquete et al. 2008) and marine mammals (Rodríguez et al. 2002; Suárez et al. 2005). Dense shoals formed near the seafloor by E. anchoita as a result of daily vertical migrations (Hansen 2004), would allow predation by $P$. patagonicus in the AUCE. Therefore, $P$. patagonicus specialization on $E$. anchoita should be interpreted with caution because it is possible that the high consumption arises from the abundance of prey in the habitats used by the predator.

Molluscs and crustaceans were more consumed by $P$. patagonicus of smaller sizes than larger sizes. This behaviour was also observed in other congeners like $P$. isosceles, (García 1987) and $P$. orbignyanus (López Cazorla and Forte 2005), in which smaller sizes preyed more on crustaceans and molluscs. This pattern is probably explained by the ability of smaller fish sizes to capture small and less motile prey (e.g., molluscs and crustaceans), while bigger and more dynamic prey are captured as individuals reach greater size and experience in predation (Link et al. 2014).

The increase in the size of the consumed prey can be attributed to the increase in the size of the predator's mouth (Stoner and Livingston 1984; Mittelbach and Persson 1998), or to the elevated metabolic requirement for movement, growth and reproduction that is supported by the consumption of prey with higher energy value (Scharf et al. 2000). In this sense, pelagic fish have a higher lipid content and therefore a higher amount of calories (Massa et al. 2013); e.g. E. anchoita has a value of $129 \mathrm{kcal}$ and T. lathami of $149 \mathrm{kcal}$, whereas the squid L. sanpaulensis of $80 \mathrm{kcal}$ and Argentine red shrimp P. muelleri of $97 \mathrm{kcal}$ (Mendez et al. 1996; Celik 2008). Thus, as flounders grow, they need to feed on prey that meets their basic energy requirements, which would be achieved with the increasing consumption of small pelagic fish.

Finally, the estimated TL (4.16) allowed the identification of the Patagonian flounder as a tertiary ichthyophagous consumer, a position similar to that outlined in the southern coasts of Brazil $(\mathrm{TL}=4.18$; Carneiro 1995). It represents an important predator of the Argentine anchovy $(E$. anchoita), which is the pelagic species with the highest abundance and widest geographic distribution in the Southwest Atlantic, ranging from $24^{\circ} \mathrm{S}$ to $48^{\circ} \mathrm{S}$, with biomass estimates in the order of 5,000,000 t (Hansen et al. 2010). This characteristic highlights the role of $P$. patagonicus in regulating the abundance of its prey, among which the main prey not only represents the sustenance of a large number of marine fish, mammals and birds but it also contributes to be an important fishery resource in the AUCE (Hansen et al. 2010).

\section{ACKNOWLEDGMENTS}

Authors thank the people involved in the project Especies Demersales Costeras from Instituto Nacional de Investigación y Desarrollo Pesquero (INIDEP, Argentina) for their kind predisposition to prepare this work. To colleagues A. Jaureguizar, J. Waessle and J. Rodriguez for their contributions and collaboration. A.C.M. wants to acknowledge support from 'Un Solo Mar' project. We thank the two anonymous referees who provided substantial improvements to the manuscript. This work is part of the undergraduate thesis of G. Troccoli. INIDEP Contribution no 2257. 


\section{REFERENCES}

Amezcua F, Portillo A. 2010. Hábitos alimenticios del lenguado panámico Cyclopsetta panamensis (Paralichthyidae) en el Sureste del Golfo de California. Rev Biol Mar Oceanogr. 45: 335-340.

Amundsen PA, Gabler HM, Staldvik FJ. 1996. A new approach to graphical analysis of feeding strategy from stomach contents data-modification of the Costello (1990) method. J Fish Biol. 48: 607-614.

Barquete V, Bugoni L, Vooren CM. 2008. Diet of Neotropic cormorant (Phalacrocorax brasilianus) in an estuarine environment. Mar Biol. 153: 431-443.

Belleggia M, Figueroa DE, SÁnchez F, BreMEC C. 2011. The feeding ecology of Mustelus schmitti in the southwestern Atlantic: geographic variations and dietary shifts. Environ Biol Fish. 95: 99-114.

Belleggia M, Figueroa D, SÁnchez F, BremeC C. 2012. Long-term changes in the spiny dogfish (Squalus acanthias) trophic role in the southwestern Atlantic. Hydrobiologia. 684: 57-67.

BergonZi C. 1997. Interrelaciones tróficas de algunas especies de peces del área costera de la Provincia de Buenos Aires [tesis de licenciatura]. Mar del Plata: Facultad de Ciencias Exactas y Naturales, Universidad Nacional de Mar del Plata, $27 \mathrm{p}$.

BOWMAN RE. 1986. Effect of regurgitation on stomach content data of marine fishes. Environ Biol Fish. 16 (1): 171-181.

CARneIRo MH. 1995. Reprodução e alimentação dos linguados Paralichthys patagonicus e Paralichthys orbignyanus (Pleuronectoformes: Bothidae), no Rio Grande do Sul, Brasil [tesis de mestrado]. Río Grande: Universidad de Río Grande. 181 p.

Carozza C, Lasta C, Ruarte C, Cotrina C,
Mianzan H, Acha M. 2004. Corvina rubia (Micropogonias furnieri). In: SÁNCHEZ RP, BEzzI S, editors. El Mar Argentino y sus recursos pesqueros. Tomo 4. Los peces marinos de interés pesquero. Caracterización biológica y evaluación del estado de explotación. Mar del Plata: Instituto Nacional de Investigación y Desarrollo Pesquero (INIDEP). p. 255-270.

CELIK M. 2008. Seasonal changes in the proximate chemical compositions and fatty acids of chub mackerel (Scomber japonicus) and horse mackerel (Trachurus trachurus) from the north eastern Mediterranean Sea. Int J Food Sci Tech. 5: 933-938.

Correa P. 2011. Estimación y análisis del consumo de alimento en peces del Río de la Plata y Costa Atlántica Uruguaya [tesis de grado]. Facultad de Ciencias, Universidad de la República. $46 \mathrm{p}$.

CORTÉs E. 1997. A critical review of methods of studying fish feeding based on analysis of stomach contents: application to elasmobranches fishes. Can J Fish Aquat Sci. 54: 726-738.

CORTÉS E. 1999. Standardized diet compositions and trophic levels in sharks. ICES J Mar Sci. 56: 707-717.

[CTMFM] COMISIÓN TÉCNICA MiXTA DEL Frente MArítimo. 2021. Desembarques del área del tratado. [accessed 2021 November]. http://www.ctmfm.org/archivos-de-captura/.

DíAZ DE Astarloa JM. 2005. Osteología craneal comparada de tres especies de lenguado del Género Paralichthys (Pleuronectiformes, Paralychthyidae) del Atlántico suroccidental. Rev Chil Hist Nat. 78: 343-391.

ELTON C. 1927. Animal ecology. New York: Macmillan. 209 p.

FABRÉ NN. 1992. Análisis de la distribución y dinámica poblacional de lenguados de la Provincia de Buenos Aires (Pisces, Bothidae) [tesis doctoral]. Mar del Plata: Facultad de Ciencias Exactas y Naturales, Universidad Nacional de Mar del Plata. 266 p. 
Fernández Aráoz NC, Lagos N, Carozza C. 2010. Asociación Íctica Costera Bonaerense "Variado Costero". Capturas declaradas por la flota comercial argentina durante el año 2009. Inf Téc INIDEP No 34/2010. 32 p.

Froese R, Pauly D. 2019. FishBase. www.fishbase.org/.

GARCíA M. 1987. Pleuronectiformes de la Argentina, IV. Alimentación de Paralichthys isosceles (Bothidae, Paralichthinae). Rev Mus La Plata (Nueva Serie) (Secc Zool). 21: 111-125.

GiBerTo DA. 2008. Estructura de la comunidad bentónica y ecología trófica de Scienidae (Phisces; Osteichthyes) en el Estuario del Río de la Plata [tesis doctoral]. Universidad Nacional del Comahue. 224 p.

Guerrero RA, Acha M, Framiñan MB, Lasta C. 1997. Physical oceanography of the Río de la Plata Estuary, Argentina. Cont Shelf Res. 17: 727-742.

HANSEN JE. 2004. Anchoíta (Engraulis anchoita). In: SÁNCHez RP, Bezzi S, editors. El Mar Argentino y sus recursos pesqueros. Tomo 4. Los peces marinos de interés pesquero. Caracterización biológica y evaluación del estado de explotación. Mar del Plata: Instituto Nacional de Investigación y Desarrollo Pesquero (INIDEP). p. 101-115.

Hansen JE, Buratti CC, Garciarena AD. 2010. Diagnóstico de la población de anchoíta al sur de $41^{\circ} \mathrm{S}$ mediante un modelo de producción estructurado por edades y estimación de capturas biológicamente aceptables en el año 2010. Inf Téc Of INIDEP No 6/2010. 16 p.

HANSEN JE, Garciarena AD, BuRATTI CC. 2007. Evolución entre los años 1990 y 2006 de la población de anchoita (Engraulis anchoita) al norte de $41^{\circ} \mathrm{S}$, y estimación de una captura biológicamente aceptable durante el año 2007. Inf Téc INIDEP N ${ }^{\circ}$ 53/2007. 23 p.

Hansen JE, Madirolas A. 1996. Distribución, evaluación acústica y estructura poblacional de la anchoita. Resultados de las campañas del año 1993. Rev Invest Desarr Pesq. 10: 5-21.
Jaureguizar AJ, Milessi AC. 2008. Assessing the sources of the fishing down marine food web process in the Argentinean-Uruguayan Common Fishing Zone. Sci Mar. 72: 25-36. Koen Alonso M, Crespo EA, García NA, Pedraza SN, Coscarella M. 1998. Diet of dusky dolphins, Lagenorhynchus obscurus, in waters of Patagonia, Argentina. Fish Bull. 96: 366-374.

Lasta C, Bremec C, Mianzán H. 1998. Áreas ícticas costeras en la Zona Común de Pesca Argentino-Uruguaya (ZCPAU) y en el litoral de la provincia de Buenos Aires. In: LASTA C, editor. Resultados de una campaña de evaluación de recursos demersales costeros de la Provincia de Buenos Aires y litoral Uruguayo. Noviembre, 1994. INIDEP Inf Téc. 21: 91101.

LaWton JH, Pimm SL. 1978. Population dynamics and the length of food chains (reply). Nature. 272: 190.

LiNDEMAN RL. 1942. The trophic-dynamic aspect of ecology. Ecology. 23: 399-418.

LinK JS, Bolles K, Milliken CG. 2002. The feeding ecology of flatfish in the Northwest Atlantic. J Northw Atl Fish Sci. 30: 1-17.

Link JS, Smith BE, Packer DB, Fogarty MJ, LANGTON RW. 2014. The trophic ecology of flatfishes. In: GIBSON RN, NASH RDM, GEFFEN AJ, VAN DER VEeR HW, editors. Flatfishes: biology and exploitation. Hoboken: John Wiley \& Sons p. 283-313.

López Cazorla A, Forte S. 2005. Food and Feeding Habits of Flounder Paralichthys orbignyanus (Jenyns, 1842) in Bahía Blanca Estuary, Argentina. Hydrobiologia. 549: 251257.

Lucas AJ, Guerrero R, Mianzan H, Acha M, LASTA C. 2005. Coastal oceanographic regimes of the Northern Argentine Continental Shelf $\left(34^{\circ}-43^{\circ} \mathrm{S}\right)$. Estuar Coast Shelf Sci. 65: 405-420.

[MAGyP] Ministerio DE AGRicultura GanadeRÍA Y PESCA. 2021. Desembarques de capturas 
marítimas totales. [accessed 2021 November]. https://www.magyp.gob.ar/sitio/areas/pesca maritima/desembarques/.

Marques JF, Teixeira CM, Pinheiro A, Peschke E, CABRAL HN. 2009. A multivariate approach to the feeding ecology of the Channel flounder, Syacium micrurum (Pisces, Pleuronectiformes), in Cape Verde, Eastern Atlantic. Cienc Mar. 35: 15-27.

Massa A, Hozbor N, Colonello J. 2004. Situación actual y avances en el estudio de los peces cartilaginosos. Inf Téc Int DNI-INIDEP No $^{\mathrm{s}}$ 57/2004. 18 p.

Massa AE, Fernández Compás AS, Pennisi FARell SC, Manca EA. 2013. Composición química y perfil de ácidos grasos de la anchoíta bonaerense en función del tamaño de los ejemplares y la zona de pesca. Rev Invest Desarr Pesq. 23: 161-174.

Mauco L, FaVero M. 2004. Diet of the common tern (Sterna hirundo) during the nonbreeding season in Mar Chiquita Lagoon, Buenos Aires, Argentina. Ornit Neot. 15: 121-131.

Mauco L, Favero M, Bó MS. 2001. Food and feeding biology of the Common Tern during the nonbreeding season in Samborombón Bay, Buenos Aires, Argentina. Waterbirds. 24: 8996.

Mendez E, GonzÁlez R, Inocente G, Giudice H, GROMPONE M. 1996. Lipid content and fatty Acid composition of fillets of six fishes from the Rio de la Plata. J Food Compos Anal. 9: $163-170$.

MENNI RC. 1983. Los peces en el medio marino. Buenos Aires: Estudio SIGMA. 169 p.

Milessi AC. 2008. Modelación ecotrófica para el Ecosistema Costero Bonaerense $\left(34^{\circ}-41^{\circ} \mathrm{S}\right)$ años '81-83. Inf Téc INIDEP No 8/2008. 55 p.

Milessi AC, MARÍ N. 2012. Ecología trófica del pez palo, Percophis brasiliensis (Quoy \& Gaimard, 1825) en el Ecosistema Costero Argentino-Uruguayo (34-41 $\left.{ }^{\circ} \mathrm{S}\right)$. Inf Invest INIDEP $\mathrm{N}^{\mathrm{o}} 65 / 2012.12 \mathrm{p}$.

Mittelbach GG, Persson L. 1998. The ontoge- ny of piscivory and its ecological consequences. Can J Fish Aquat Sci. 55: 1454-1465.

Norbis W, Galdi O. 2004. Feeding habits of the flounder Paralichthys orbignyanus (Valenciennes, 1842) in a shallow coastal lagoon of the southern Atlantic Ocean: Rocha, Uruguay. Cienc Mar. 30: 619-626.

Odum WE, Heald EJ. 1975. The detritus-based food web of an estuarine mangrove community. In: CRONIN LE, editor. Estuarine research. Vol. 1. New York: Academic Press. p. 265286.

PÁjaro M, Hansen Je, Leonarduzzi E, GarciaRENA AD. 2009. Biomasa de los reproductores de la población bonaerense de anchoita (Engraulis anchoita) en el año 2008: estimación mediante el método de producción diaria de huevos. Inf Téc Of INIDEP N ${ }^{\circ}$ 29/2009. 19 p.

Pinkas LM, Oliphant S, Iverson ILK. 1971. Food habits of albacore, bluefin tuna and bonito in Californian waters. Calif Fish Game. 152: 1-105.

Rico MR. 2010. Pesquería de lenguados en el ecosistema costero bonaerense al norte de $39^{\circ}$ S. Frente Marít. 21: 129-135.

Rico MR, Lagos AN. 2010. Lenguados del sistema costero bonaerense. Herramientas para la identificación de especies. Inf Téc Of INIDEP $\mathrm{N}^{\mathrm{o}} 58 / 2010.15 \mathrm{p}$.

Rico MR, Perrotta RG. 2009. Análisis de la captura y el esfuerzo de pesca aplicado al grupo lenguados en el área costera bonaerense. Período 1981-2005. Inf Téc Of INIDEP N ${ }^{\circ}$ 35/2009. 22 p.

Riestra MC. 2010. Edad, crecimiento e influencia del ambiente en la distribución de Paralichthys patagonicus en el Sistema Costero del Atlántico Sudoccidental $\left(34^{\circ}-41^{\circ} \mathrm{S}\right)$ [tesis de grado]. Mar del Plata: Facultad de Ciencias Exactas y Naturales, Universidad Nacional de Mar del Plata. 55 p.

Riestra MC, Díaz de Astarloa JM, Vieira JP, Buratti CC, Irigoyen AJ, Landaeta M, 
HÜNE M. 2020. Paralichthys patagonicus. The IUCN Red List of Threatened Species 2020: e.T195089A165017727.

Rodríguez D, Rivero L, BASTIDA R. 2002. Feeding ecology of the Franciscana (Pontoporia blainvillei) in marine and estuarine waters of Argentina. LAJAM. 1: 77-94.

SÁNCHEZ MF. 2002. Alimentación de la merluza (Merluccius hubbsi) en la Zona Común de Pesca Argentino-Uruguaya entre los años 1995 y 2000. Inf Téc Int-DNI INIDEP $\mathrm{N}^{\mathrm{o}}$ 118/2002. 14 p.

SÁnchez MF, DíAZ de Astarloa JM. 1999. Alimentación del lenguado Paralichthys patagonicus. $8^{\circ}$ COLACMAR, Congreso Latinoamericano Ciencias del Mar. Trujillo, Perú. p. 186188.

Scharf FS, Juanes F, Rountree RA. 2000. Predator size-prey size relationships of marine fish predators: interespecific variation and effects of ontogeny and body size trophic-niche breadth. Mar Ecol Prog Ser. 208: 229-248.

Silva M, Bastida R, Darrieu C. 2000. Dieta de la gaviota cocinera (Larus dominicanus) en zonas costeras de la provincia de Buenos Aires, Argentina. Ornit Neot. 11: 331-339.
Sterner RW, Bajpai A, Adams T. 1997. The enigma of food chain length: absence of theoretical evidence for dynamic constraints. Ecology. 78: 2258-2262.

Stoner AW, Livingston RJ. 1984. Ontogenetic patterns in diet and feeding morphology in sympatric sparid fishes from seagrass meadows. Copeia. 1984 (1): 174-187.

Suarez AA, Sanfelice D, Cassini MH, Cappozzo HL. 2005. Composition and seasonal variation in the diet of the South American Sea Lion (Otaria flavecens) from Quequén, Argentina. LAJAM. 4 (2): 163-174.

Vögler R, Milessi AC, Duarte LO. 2009. Changes in trophic level of Squatina guggenheim with increasing body length: relationships with type, size and trophic level of its prey. Environ Biol Fish. 84: 41-52.

VÖGLer R, Milessi AC, QuiÑONes RA. 2003. Trophic ecology of Squatina guggenheim on the continental shelf off Uruguay and northern Argentina. J Fish Biol. 62: 1254-1267.

WaEssle JA, LAsta C, Favero M. 2003. Otolith morphology and body size relationships for juvenile Sciaenidae in the Río de la Plata Estuary (35-36 ${ }^{\circ}$ S). Sci Mar. 67: 233-240. 